\title{
Narrativas curtas de Émile Zola: aspectos da recepção da obra do escritor no Brasil entre 1860 e 1914
}

\author{
Eduarda Araújo da Silva Martins ${ }^{1}$ \\ Pedro Paulo Garcia Ferreira Catharina ${ }^{2}$
}

\begin{abstract}
Resumo: Neste artigo, ao mapearmos as narrativas curtas de autoria do escritor francês Émile Zola (1840-1902), entre 1860 e 1914, publicadas em periódicos das regiões Norte e Nordeste do Brasil, buscamos destacar, no âmbito da obra do escritor, um conjunto de textos geralmente colocados em segundo plano em relação à sua produção romanesca naturalista, estética e simbolicamente mais valorizada pela crítica e pela pesquisa acadêmica. Este artigo apresentará, portanto, uma análise das características estéticas de parte desses contos e novelas, frequentemente associados a uma fase romântica e juvenil do escritor, no intuito de destacar seu lugar como parte constitutiva da obra de Zola. Através da pesquisa de fontes, pela recuperação de textos literários do passado inseridos nos modos de funcionamento da imprensa brasileira oitocentista, acrescentamos novos dados sobre a recepção de Zola no Brasil, trazendo à luz traços dos gostos e preferências dos leitores brasileiros do século XIX e início do século XX.
\end{abstract}

Palavras-chave: Contos e novelas. Émile Zola. Naturalismo. Imprensa brasileira. Recepção.

Muito antes de se tornar conhecido por sua polêmica obra romanesca e pela recolha de textos teóricos $O$ Romance Experimental, na qual tentava estabelecer de modo mais contundente a estética naturalista na França, Émile Zola havia publicado em 1864, pela Librairie Internationale de Lacroix \& Verboeckhoven editores, um volume intitulado Contos a Ninon (Contes à Ninon). O livro continha "Simplice", "Le carnet de danse", "Celle qui m’aime”, "La fée amoureuse", "Le sang”, "Les voleurs et l'âne”, “Sœur-des-Pauvres" e "Les aventures du grand Sidoine et du petit Médéric". Esses contos, no entanto, não eram inéditos, pois já haviam sido publicados na imprensa entre 1859 e 1864 . Naquele momento de sua carreira, Zola não gozava ainda de reconhecimento como escritor e trabalhava como chefe de

\footnotetext{
${ }^{1}$ Doutoranda e Mestre em Letras Neolatinas (UFRJ). Tutora-coordenadora de Letras (UFF/CEDERJ). Professora substituta de Letras do IFF (Campos-Centro). Rio de Janeiro. Brasil. E-mail: eduarda.araujosm@gmail.com Orcid: https://orcid.org/0000-0002-8589-9574

${ }^{2}$ Doutor em Letras Neolatinas (UFRJ), Professor Associado da UFRJ, Líder do Grupo ARS - ArteRealidade-Sociedade (CNPq-FBN). Rio de Janeiro. Brasil. E-mail: pedrop@letras.ufrj.br Orcid: https://orcid.org/0000-0002-8104-1773
} 
publicidade na Librairie Hachette, onde permaneceu até 1866 (MITTERAND, 1999, p. 321327). Seu trabalho na editora ajudou-o a compreender os meios para se estabelecer como escritor. Na ocasião da publicação de Contos a Ninon, Zola utiliza expedientes do métier a fim de promover o livro, tendo provavelmente escrito resenhas elogiosas de próprio punho (VAN TOOREN, 1998, p. 35; MITTERAND, 1999, p. 410-412). Essas estratégias funcionavam como um modo de o escritor conquistar seus primeiros leitores e de impor seu nome de autor.

Segundo van Tooren, em um dos poucos estudos sobre as narrativas curtas do escritor, Zola havia confessado ao amigo Antony Valabrègue que "ele considerava sua primeira coletânea de contos como uma espécie de trampolim, como um meio sério para conquistar o sucesso"3 (1998, p. 34). O lançamento de Contos a Ninon obteve boa repercussão, apesar da tiragem de apenas 1.500 exemplares (BECKER et al., 1993, p. 89; MITTERAND, 1999, p. 408-413), tendo sido uma tentativa inicial bem-sucedida do escritor para ingressar no campo literário francês. ${ }^{4}$

A partir de 1865, Zola busca se firmar sobretudo como romancista e lança pela editora de Albert Lacroix A Confissão de Claude (La Confession de Claude, 1865), Os Mistérios de Marselha (Les Mystères de Marseille, 1867), Thereza Raquin (Thérèse Raquin, 1867) e Magdalena Férat (Madeleine Férat, 1868). Na sequência, publica pela mesma editora os dois primeiros romances que constituirão a série Os Rougon-Macquart; história natural e social de uma família no Segundo Império (1871-1893). Trata-se de A Fortuna dos Rougon (La Fortune des Rougon, 1871) e O Regabofe (La Curée, 1872). Em 1872, Zola dará um passo fundamental em sua carreira ao assinar um contrato com Georges Charpentier, filho de Gervais Charpentier. ${ }^{5}$ George Charpentier publicará toda a saga dos Rougon-Macquart, comprando de Albert Lacroix os direitos das obras já publicadas (BECKER et al., 1993, p. 219). A partir de então, Charpentier se torna o principal editor de Zola e do grupo dos escritores naturalistas.

\footnotetext{
${ }^{3}$ As citações de obras em língua estrangeira indicadas nas Referências foram traduzidas pelos autores.

${ }^{4}$ Conceito cunhado por Pierre Bourdieu, o campo literário é um universo social estrutural e estruturante onde se encontram profissionais da produção simbólica ocupando posições determinadas uns em relação aos outros em busca de capitais específicos (econômico, social, simbólico) (BOURDIEU, 1996).

${ }^{5}$ Gervais Charpentier provocou uma revolução técnica, comercial e editorial com a criação, em 1838, da "Bibliothèque Charpentier". Essa coleção apresentava um novo formato, menor e mais condensado, que permitiu abaixar o preço do livro e alcançar o público cativo dos gabinetes de leitura (OLIVERO, 1999).
} 


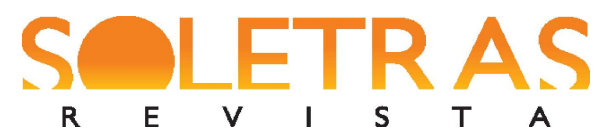

N. 40 - 2020.2 - EDUARDA ARAÚJO DA SILVA MARTINS PEDRO PAULO GARCIA FERREIRA CATHARINA

Ao mesmo tempo que investe fortemente em narrativas longas, Zola lança ainda, em 1866, pela editora de Achille Faure, com o título Esboços Parisienses (Esquisses parisiennes), um volume contendo um romance com características folhetinescas intitulado O Desejo de uma morta (Le Vou d'une morte) - publicado anteriormente pelo jornal L'Événement -, seguido de quatro novelas que tratam da vida de mulheres parisienses desfavorecidas economicamente, também publicadas em periódicos (BECKER et al., 1993, p. 134; 450). O romance e as novelas ganharão igualmente uma nova edição pela editora Charpentier em 1889.

Em 1874, enquanto elaborava o quinto volume dos Rougon-Macquart e dez anos depois da publicação de Contos a Ninon, já com maior acúmulo de capital simbólico devido às suas investidas no campo literário, Zola lançou uma nova coletânea de contos, já publicados na imprensa entre 1867 e 1873, intitulada Novos Contos a Ninon (Nouveaux Contes à Ninon), contendo 14 textos: "Un bain”, "Les Fraises", "Le grand Michu”, "Le jeûne”, "Les épaules de la marquise", "Mon voisin Jacques", "Le paradis des chats", "Lili", "La Légende du PetitManteau bleu de l'amour", "Le forgeron", "Le chômage", "Le petit village”, "Souvenirs" e "Les quatre journées de Jean Gourdon" (que se divide em "Printemps”, “Été”, “Automne” e "Hiver"). Ao contrário do que se nota em Contos a Ninon, volume em que se identifica uma outra perspectiva ficcional abarcando desde os contos de fadas até as novelas satíricas, revelando assim o confronto inicial do escritor com a noção de real (BECKER et al., 1993, p. 87), em Novos Contos a Ninon já entrevemos a estética naturalista que se firmava na sua escrita.

$\mathrm{Na}$ década seguinte, Zola lança ainda dois volumes de narrativas curtas compostos por novelas não inéditas, ambos pela editora Charpentier: O Capitão Burle (Le Capitaine Burle, 1882), contendo "Le Capitaine Burle”, “Comment on meurt", "Pour une nuit d'amour", “Aux champs", "La fête à Coqueville" e "L'inondation"; e Naïs Micoulin (1883), que trazia "Naïs Micoulin", "Nantas", "La Mort d'Olivier Bécaille", "Madame Neigeon”, "Les coquillages de M. Chabre" e "Jacques Damour". Há ainda "O Assalto ao moinho" (L'Attaque du moulin), novela publicada pela editora Charpentier, em 1880, na obra Os Saraus de Médan (Les Soirées de Médan), a qual reunia mais cinco novelas sobre a Guerra Franco-Prussiana produzidas por escritores que partilhavam afinidades estéticas com Zola e se reuniam em sua casa de Médan, a fim de discutir questões e estratégias literárias: Guy de Maupassant, J.-K. Huysmans, Henry Céard, Léon Hennique e Paul Alexis (BAGULEY, 1995, p. 21-26). Publicada no mesmo ano 


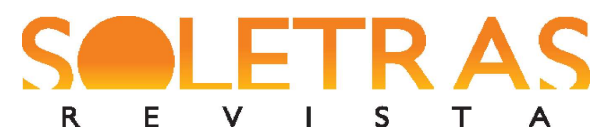

N. 40 - 2020.2 - EDUARDA ARAÚJO DA SILVA MARTINS PEDRO PAULO GARCIA FERREIRA CATHARINA

de $O$ Romance Experimental e do romance Naná, "O Assalto ao moinho" se diferencia das narrativas citadas anteriormente, por pertencer integralmente ao projeto naturalista de Zola.

No total, são 39 narrativas curtas publicadas em volume entre 1864 e 1883 - 8 contos em Contos a Ninon; 4 novelas em Esboços Parisienses; 14 contos em Novos Contos a Ninon; 6 novelas em O Capitão Burle; 6 novelas em Naïs Micoulin; e 1 novela em Os Saraus de Médan. ${ }^{6}$ Segundo van Tooren, Zola não teria dado muita importância aos seus contos e novelas, tendo preferido apostar em uma ambiciosa carreira de romancista, simbólica e financeiramente mais rentável. No entanto, trata-se de um número considerável de narrativas curtas, não negligenciáveis em uma trajetória tão sólida como a construída pelo escritor. A publicação de boa parte dos contos se faz paralelamente à escrita e publicação dos romances. Contudo, pouco se fala em Zola como contista ou novelista. Existiriam duas razões para esse desinteresse, tanto por parte do público quanto dos estudos acadêmicos, que teriam levado ao atual esquecimento de suas narrativas curtas. A primeira devido à própria opinião negativa do escritor; e a segunda pelo fato de as narrativas curtas apresentarem diferenças fundamentais para com a produção romanesca naturalista que viria a consagrar definitivamente o escritor (VAN TOOREN, 1998, p. 34).

Um escritor que renega o início de sua carreira, os primeiros passos vacilantes durante os quais adota um gênero de menor extensão, que exigiria menor esforço ou talento do autor, é narrativa corrente no meio literário. ${ }^{7}$ Esse tipo de posicionamento, do qual o pesquisador deve suspeitar, não invalida o estudo da produção renegada. Por outro lado, a pesquisa em periódicos do passado revelou forte apreço do público pelas narrativas curtas de Zola no Brasil do Oitocentos, em paralelo à produção romanesca que circulava nos jornais em forma de folhetim e também em volume. Esse fato indica que, embora o silêncio da crítica coetânea e atual tenha contribuído para um progressivo apagamento de Zola como escritor de narrativas curtas, o público brasileiro acolheu bem esses textos naquele período.

Nosso objetivo neste artigo é investigar a presença das narrativas curtas de Émile Zola na imprensa brasileira nas regiões atualmente chamadas Norte e Nordeste durante o "longo

\footnotetext{
${ }^{6}$ Entre uma centena de contos e novelas publicados na imprensa (BECKER et al., 1993, p. 87).

${ }^{7}$ Maupassant, escritor naturalista, menosprezou o gênero que o consagrou, atribuindo ao romance maior valor simbólico: "Estou [...] decidido a não fazer mais contos nem novelas. Está desgastado, acabado, ridículo. [...] Quero trabalhar apenas nos meus romances" (Carta a um editor de revista em 24/10/1891. MAUPASSANT, 1891).
} 


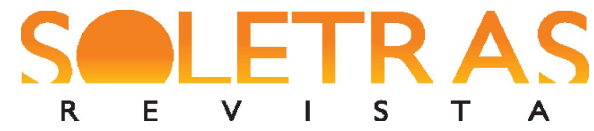

$\mathbf{R}$
$T$
N. 40 - 2020.2 - EDUARDA ARAÚJO DA SILVA MARTINS PEDRO PAULO GARCIA FERREIRA CATHARINA

século XIX”, observando sua natureza estética bem como as preferências do leitor brasileiro. Para isso, efetuamos considerações sobre a literatura veiculada na imprensa no Oitocentos em seus aspectos multiculturais e apresentamos o levantamento dos dados realizado por meio da Hemeroteca Digital Brasileira da Fundação Biblioteca Nacional, destacando as narrativas curtas de Zola encontradas na imprensa nas referidas regiões. Em seguida, analisamos os contos e as novelas que tiveram maior incidência naquelas regiões, para enfim refletirmos acerca da importância dessas narrativas dentro da obra do escritor, observando suas características estéticas.

\section{A literatura nas páginas dos jornais}

A pesquisa de fontes primárias no Brasil tem sido de grande importância para o entendimento da circulação e da recepção de obras do passado, incluindo aquelas de escritores estrangeiros, implicando uma ampliação da colaboração internacional entre pesquisadores nos estudos sobre a obra de um autor. ${ }^{8}$ Assim, é possível identificar, ao levantarmos e analisarmos os dados obtidos por meio digital, como de fato ocorreu a difusão e a recepção de determinada obra literária no país. É o caso de nosso estudo sobre a presença do nome de Émile Zola no Brasil. Por meio de ferramentas de busca, identificamos as obras do escritor que apareceram traduzidas nas regiões Norte e Nordeste do país, as antigas Províncias do Norte, ${ }^{9}$ distantes do eixo cultural Rio-São Paulo, mas que demonstravam à época intenso contato com a cultura europeia e, particularmente, a francesa, contradizendo o lugar-comum do histórico atraso cultural das regiões. Nelas encontramos mais de 3.000 referências $^{10}$ ao nome do escritor francês entre os anos de 1860, década de publicação da primeira obra literária de Zola, e 1914, ano que

\footnotetext{
${ }^{8}$ Referimo-nos aqui sobretudo ao universo de pesquisa que se descortinou a partir da utilização da Hemeroteca Digital Brasileira da Fundação Biblioteca Nacional.

${ }^{9}$ Nosso período abarca parte do Império e as primeiras décadas da República. Por questões operacionais, utilizamos a divisão geográfica atual, ressaltando que os estados das regiões Norte e Nordeste eram conhecidos como "Províncias do Norte". O ponto de referência era a capital - Rio de Janeiro - tanto durante o Império quanto após a proclamação da República. Desse modo, havia as Províncias do Norte, que ficavam ao Norte da capital e as Províncias do Sul que se localizavam ao Sul do Rio de Janeiro (FERNANDES, 2014).

${ }^{10}$ Dados colhidos até 2017, no âmbito deste trabalho.
} 


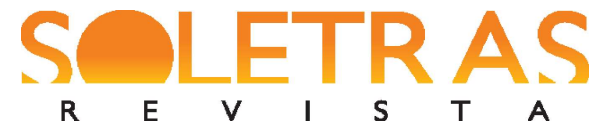

$\mathbf{R}$
$T$
N. 40 - 2020.2 - EDUARDA ARAÚJO DA SILVA MARTINS PEDRO PAULO GARCIA FERREIRA CATHARINA

marca o final do "longo século XIX" (HOBSBAWN, 1977; 1979; 1988). ${ }^{11}$ O nome de Émile Zola apareceu em notícias diversas, reportagens, menções, citações de seus textos, críticas de suas obras, anúncios de livros, peças e filmes, além de obituários e obras traduzidas e publicadas no interior de periódicos. Neste artigo, examinaremos esta última categoria.

O século XIX foi marcado por uma série de inovações tecnológicas como a produção em larga escala de papel a preços mais baixos e a criação da prensa a vapor, que resultaram no aumento da produção dos impressos (ABREU, 2011). Na Europa, essas inovações aconteceram simultaneamente à ampliação do público leitor. A França sofreu significativas mudanças em seu sistema de ensino ao longo do período, fato que contribuiu para o maior consumo de periódicos e livros, sobretudo na segunda metade do século, quando grande parte da população já estava alfabetizada (CHARLE, 2001). Segundo Abreu, em 1839, 55\% da população francesa sabia ler, ou seja, cerca de 19,5 milhões de pessoas. No mesmo ano, $67 \%$ dos homens e $51 \%$ das mulheres eram leitores na Inglaterra, contabilizando 8,8 milhões de leitores. Em 1850, 15\% da população portuguesa era alfabetizada (ABREU in ABREU, 2016, p. 376-377).

Como se pode notar, durante o século XIX, boa parte da Europa passou por um processo de alfabetização em massa. Por outro lado, a América Latina carece de informações mais precisas sobre o número dos alfabetizados no período. No Brasil, por exemplo, não há dados oficiais que confirmem o número de leitores no início do século XIX - o primeiro censo demográfico tendo sido realizado apenas em $1872 .{ }^{12}$ No entanto, sabemos - e os dados encontrados em periódicos da época o confirmam - que o Brasil não só possuía população letrada como também mantinha forte conexão cultural com a Europa (ABREU, 2016; GRANJA; LUCA, 2018; PONCIONI; LEVIN, 2018), sobretudo após a instalação do cabo telegráfico ligando o Brasil ao continente europeu, em 1874.

Conforme demonstraram os resultados de pesquisas do projeto "Circulação transatlântica dos impressos - A globalização da cultura no século XIX”, realizado por pesquisadores do Brasil, França, Portugal e Inglaterra, "as fronteiras nacionais não são um empecilho para o trânsito de livros, revistas, espetáculos e impressos em geral" (ABREU;

\footnotetext{
${ }^{11}$ O "longo século XIX" compreende o período entre a Revolução Francesa (1789) - marcado pelo aumento gradativo na produção e circulação dos impressos entre os países do globo - e o início da Primeira Guerra Mundial (1914) - quando a circulação dos impressos diminui significativamente.

${ }^{12}$ Consultar: https://memoria.ibge.gov.br/sinteses-historicas/historicos-dos-censos/panorama-introdutorio.html.
} 


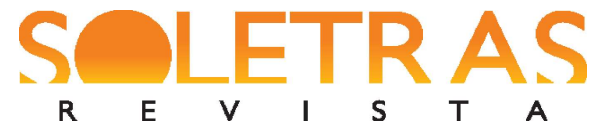

$\mathbf{R}$

N. 40 - 2020.2 - EDUARDA ARAÚJO DA SILVA MARTINS PEDRO PAULO GARCIA FERREIRA CATHARINA

MOLLIER in ABREU, 2016, p. 11). O Brasil participava de uma comunidade letrada internacional que não só compartilhava os mesmos gostos literários, como as mesmas ideias (ABREU in ABREU, 2016, p. 365-394). O fato de o Brasil possuir, ao longo do século XIX, um número ainda reduzido de leitores, não o coloca alheio ao consumo de bens culturais globalizados, a diferença entre o consumo da Europa e do Brasil sendo mais uma questão de escala do que de natureza (ABREU, 2019, p. 280). Ou seja, as diferenças em relação à quantidade de leitores não afetam o trânsito de livreiros e informações entre os dois continentes. Se antes de 1808 a impressão de livros e periódicos era proibida no país, a vinda da família real para o Brasil mudou esse cenário. Em 1808, foi criada a Impressão Régia. Além da publicação de periódicos, textos literários como o romance Paulo e Virgínia (Paul et Virginie, 1788), de Bernardin de Saint-Pierre, saíram dos seus prelos (MARTINS in SIMÕES JÚNIOR et al., 2009, p. 29). Trata-se de um passo decisivo não só para a circulação das notícias e das ideias entre o Brasil e a Europa como também para a intensificação das trocas culturais entres os países.

O primeiro periódico a ser publicado no Brasil foi a Gazeta do Rio de Janeiro, jornal oficial da Coroa Portuguesa. Ele lançava notas oficiais do governo e publicava notícias vindas do mundo através dos navios. Segundo Barbosa, essa era uma característica dos periódicos do início do século XIX: "todos copilavam notícias já publicadas em outros lugares e países" (BARBOSA, 2008, p. 95). O crescimento da imprensa só ocorreria de maneira mais significativa a partir de 1821 , quando D. Pedro I decretou o fim censura. A partir de então, notase um elo mais estreito entre as práticas jornalísticas e a literatura.

De maneira similar ao que acontecia na França, a presença da literatura nos jornais torna-se prática frequente no Brasil. Deve-se destacar que, no início do século XIX, ao lado das folhas de tendências políticas diversas, circulavam as revistas que se ocupavam, mais especificamente, de conteúdo literário. Embora não tivessem o texto literário como foco, os jornais eram também "dominados pelo viés literário", uma vez que publicavam alguns excertos no interior de suas páginas, assim como apresentavam uma "estetização da palavra". Ao longo do Segundo Reinado (1840-1889), no entanto, as diferenças entre jornais e revistas parecem diminuir: os jornais se tornam o suporte não só do texto político e noticioso, mas também do texto ficcional (MARTINS in SIMÕES JÚNIOR et al., 2009, p. 27-44) 


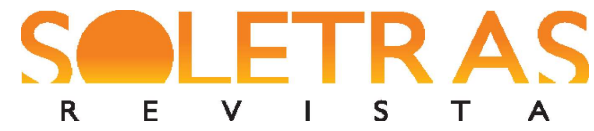

S $\quad$ A N $40-2020.2$ - EDUARDA ARAÚJO DA SILVA MARTINS PEDRO PAULO GARCIA FERREIRA CATHARINA

A literatura se vê cada vez mais presente nas páginas dos jornais, sendo frequentemente de autoria dos próprios jornalistas. A proclamação da República, em 1889, não alterou o jornalismo político-literário, mas promoveu a diversificação de textos e de autores. Convivem nos periódicos escritores realistas, naturalistas, parnasianos, simbolistas, decadentistas, regionalistas e pré-modernistas, “por vezes conjugando suas vozes numa mesma publicação, convivendo em espaços comuns, confundindo-se e transmudando-se ao longo daquela primeira República das Letras" (MARTINS in SIMÕES JÚNIOR et al., 2009, p. 38). Soma-se ao funcionamento da imprensa a importante atuação de livreiros-editores estrangeiros como os irmãos Laemmert e Baptiste-Louis Garnier - este último tendo instalado no Rio de Janeiro uma das mais importantes editoras do país - a Livraria Garnier -, que editava obras nacionais e internacionais (HALLEWELL, 2012; GRANJA, 2016 in GRANJA; LUCA, 2018, p. 55-79), colaborando significativamente para as trocas culturais entre a França e o Brasil.

No contexto de triunfo do sistema midiático e das trocas culturais, a literatura encontra lugar para se difundir e se modificar. Em 1836, o escritor francês Honoré de Balzac publicou o que foi considerado o primeiro romance seriado em jornal, A Solteirona (La Vieille Fille), na seção "Variedades" do periódico La Presse. A prática se populariza e os romances ganham destaques não mais no corpo do jornal, mas no seu rodapé. Os romances-folhetim mudam a forma de contato entre escritor e leitor, e o jornal se torna um laboratório para os escritores oitocentistas que alteram sua escrita de acordo com o gosto do público. ${ }^{13}$

Nesse espaço dinâmico que foi o jornal do Oitocentos, tanto na França quanto no Brasil, a produção literária é determinada pela proximidade dos gêneros jornalísticos em seus critérios de periodicidade, coletividade, rubricagem e atualidade, levando a mutações poéticas, como nos indica Marie-Ève Thérenty. Para a pesquisadora, ocorreria, no âmbito da poética desse veículo de comunicação que passou a ritmar a vida das pessoas, um fenômeno de contaminação entre o que ela nomeia a matriz midiática e a matriz literária, através do efeito de porosidade. A literatura se apropria "dos resultados do laboratório jornalístico" enquanto o jornal absorve “os modos de escrita privilegiados pela literatura do século XIX” (THÉRENTY, 2007, p. 20).

\footnotetext{
${ }^{13}$ Foi o caso de Eugène Sue, que publicou entre 1842 e 1843 Os Mistérios de Paris (Les Mystères de Paris), romance que se tornou um fenômeno de globalização cultural (THÉRENTY, 2013).
} 


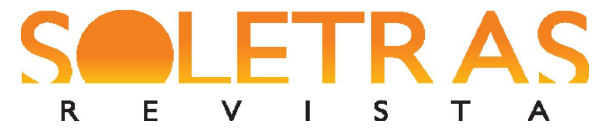

S N $\quad$ A 40 - 2020.2 - EDUARDA ARAÚJO DA SILVA MARTINS PEDRO PAULO GARCIA FERREIRA CATHARINA

Não se pode negar, portanto, que entre a literatura e os periódicos daquela época existia uma relação fundamental de trocas, responsável por constituir as próprias estruturas dos jornais e da literatura. Escritores de diferentes envergaduras no campo literário em processo de autonomização, levando-se em conta os contextos específicos de cada país, colaboravam em periódicos publicando textos literários, críticas ou artigos. Os jornais serviam, portanto, como o meio pelo qual eles se inseriam no campo literário - caso de Zola, que iniciou sua carreira publicando seus primeiros contos na imprensa, antes mesmo de lançar seu primeiro livro.

O Brasil compartilhou das mesmas técnicas literárias e midiáticas do Velho Continente, ao passo que assimilava e aclimatava poéticas literárias e jornalísticas imantadas pelo apreço por gêneros que ultrapassavam as fronteiras nacionais. A tradução tem nesse contexto um papel fundamental para a construção de referências culturais comuns, através do processo de transferências de produtos culturais entre países. ${ }^{14}$ Como mostra o trabalho pioneiro de Marlyse Meyer (1996), textos literários de escritores estrangeiros já eram traduzidos pelos jornais brasileiros desde a década de 1830 e, em forma de folhetim, mais precisamente, desde 1838 com a publicação pelo Jornal do Commercio do romance O Capitão Paulo (Le Capitaine Paul) de Alexandre Dumas, obra originalmente publicada na França no mesmo ano pelo jornal Le Siècle. A partir de então, as traduções de ficção estrangeira invadem as páginas de nossos jornais, e, por terem tido excelente acolhida do público, "parecem ter gerado efeitos sobre a dinamicidade da produção ficcional nacional", causando impacto "na nascente ficção nacional brasileira" (BEZERRA; GIMENEZ, 2019, p. 241; 243).

No período que nos interessa, então, podemos afirmar que a literatura, estrangeira ou nacional, para além da circulação em formato livro, teve nas páginas dos periódicos seu espaço preferencial de publicação e veículo de maior alcance de público. Muitas das produções literárias publicadas em jornais e revistas jamais passaram ao suporte livro. Do mesmo modo, aspectos envolvendo a preferência do público por certos textos e gêneros se apagaram com o tempo, fato auxiliado pela redução efetuada pelas Histórias Literárias e compêndios críticos.

\footnotetext{
${ }^{14} \mathrm{O}$ processo de tradução e de circulação de obras entre diferentes culturas tem sido observado por Michel Espagne e Michael Werner, que cunharam o termo "transferências culturais" para se referir a uma orientação metodológica de pesquisa tendo o objetivo de destacar as mestiçagens entre diferentes espaços nacionais. Eles se preocupam em considerar as características culturais e políticas dos locais de origem e recepção das obras e a função dos "mediadores culturais" nas trocas culturais (Espagne; WERNER, 1987; ESPAGNE, 2012; JURT, 2007).
} 


\section{Contos e novelas de Zola: uma recepção particular}

O nome de Émile Zola é sobretudo associado à sua produção romanesca naturalista. Poucos são os estudos que se debruçam sobre suas narrativas curtas que, a nosso ver, possuem um lugar importante na obra do escritor, funcionando como um laboratório para sua escrita. No Brasil, curiosamente, a imprensa oitocentista das hoje chamadas regiões Norte e Nordeste deu preferência em suas páginas aos contos e novelas do escritor. É o que constatamos pela pesquisa efetuada ao compararmos as publicações de seus contos e novelas com a dos romances traduzidos nos periódicos dessas regiões. Ao todo, apenas 5 romances do escritor apareceram em publicações seriadas entre 1860 e 1914: ${ }^{15}$ Thereza Raquin, O Dinheiro (L'Argent), $O$ Desmoronamento (La Débâcle), O Sonho (Le Rêve) e O Trabalho (Travail) (Tabela 1). Dos 5 romances, 3 apareceram no mesmo ano de suas publicações em volume na França. Esse fato evidencia que a circulação de determinadas obras literárias entre a França e o Brasil foi quase simultânea e ajuda a desmistificar a ideia de atraso cultural do Brasil em relação à Europa.

Tabela 1 - Romances

\begin{tabular}{|c|c|c|c|c|}
\hline Título & $\begin{array}{c}\text { Província / } \\
\text { Estado }\end{array}$ & Periódico & $\begin{array}{c}\text { Ano de } \\
\text { publicação } \\
\text { no Brasil }\end{array}$ & $\begin{array}{c}\text { Ano de } \\
\text { publicação em } \\
\text { volume na França }\end{array}$ \\
\hline Thereza Raquin & Ceará & Gazeta do Norte & 1880 & 1867 \\
\hline O Dinheiro & Pará & A República & 1891 & 1891 \\
\hline $\begin{array}{c}\text { O Desmoronamento } \\
\text { O Desmoronamento } \\
\text { (trechos) }\end{array}$ & Amazonas & Diário de Manaos & 1892 a 1893 & 1892 \\
\hline $\begin{array}{c}\text { O Trabalho } \\
\text { (trecho) }\end{array}$ & Maranhão & $\begin{array}{c}\text { A República, } \\
\text { Gazeta Postal }\end{array}$ & 1892 & 1892 \\
\hline O Sonho & Ceará & Jornal do Ceará & 1904 & 1901 \\
\hline
\end{tabular}

Embora a publicação de romances seja um ponto importante a se considerar quando se examina a circulação das obras de Zola na imprensa brasileira, a presença dos contos e novelas chama particular atenção por ocorrer em maior número nas regiões estudadas. Em termos percentuais, pouco mais de $16 \%$ dos romances do escritor foram traduzidos nessas regiões. Esse número é relativamente baixo, tendo em vista que Zola publicou 31 romances ao longo de sua

\footnotetext{
${ }^{15}$ Período que corresponde à década de publicação do primeiro livro de Zola e ao final do "longo século XIX".
} 
trajetória literária. Além daqueles já citados neste artigo ( $A$ Confissão de Claude, O desejo de uma morta, Os Mistérios de Marselha, Thereza Raquin e Magdalena Férat), o escritor publicou os ciclos dos Rougon-Macquart contendo 20 romances; Les Trois Villes com Lourdes (1894), Roma (Rome, 1896) e Paris (1898); e o ciclo Les Quatre Évangiles, composto por Fecundidade (Fécondité, 1899), O Trabalho (1901) e Verdade (Vérité, 1903), interrompido pela morte do escritor. Por outro lado, das 39 narrativas curtas de Zola, 17 saíram em jornais entre os anos de 1878 e 1909, ou seja, 43,5\%. Dentre elas, 7 apareceram mais de uma vez, totalizando 28 publicações.

O único texto literário de Zola encontrado nos jornais das regiões em questão na década de 1870 foi "O Paraíso dos gatos", ${ }^{16}$ sétimo conto de Novos Contos a Ninon, publicado no Monitor da Bahia em 1878. ${ }^{17}$ A década seguinte foi mais fértil, com 12 contos e novelas distribuídos entre os atuais estados da Bahia, Ceará, Maranhão, Pará, Paraíba e Pernambuco: "A Fada Amorosa" e "Simplício", de Contos a Ninon (1864); "Lili", "A Mantilha Azul do Amor", "Os Ombros da Marquesa", "Os Morangos" e "A Vilazinha"/“A Pequena Aldeia”, de Novos Contos a Ninon (1874); “A Morte do Rico" (“Comment on meurt") e "Inundação", de O Capitão Burle (1882); "Nantas" e "A Morte de Olivier Bécaille”, publicados no volume Naïs Micoulin (1883) e "O Assalto ao moinho", novela de Os Saraus de Médan (1880).

A década de 1890 foi menos expressiva que a anterior. O periódico A República do Pará publicou em 1892 o conto "O Jejum”, de Novos Contos a Ninon. O periódico O Pará lançou “Aventuras do grande Sidoine e do pequeno Médéric", de Contos a Ninon, em 1899. No Estado da Parahyba, "A Inundação", de O Capitão Burle, apareceu em 1891. "O Ferreiro" e "A Pequena aldeia", de Novos Contos a Ninon, foram publicados no Pacotilha do Maranhão em 1894. Na década seguinte o Jornal do Commercio do Amazonas publicou, em 1909, "História de um cão vadio", uma versão de "O Paraíso dos gatos", intitulada "La Journée d'un chien errant”, publicada no Figaro em 1866 (BECKER in CABANÈS; SAÏDAH, 2003, p. 337).

\footnotetext{
${ }^{16}$ Os títulos originais dos contos e das novelas estão listados na parte introdutória deste artigo. As datas precisas de publicação nos periódicos encontram-se na Tabela 2.

17 Todos os periódicos podem ser consultados em: http://memoria.bn.br/hdb/periodico.aspx
} 


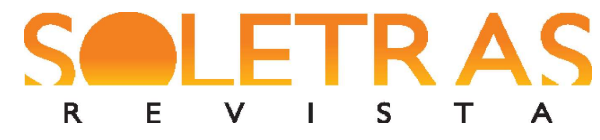

N. 40 - 2020.2 - EDUARDA ARAÚJO DA SILVA MARTINS

PEDRO PAULO GARCIA FERREIRA CATHARINA

Tabela 2 - Contos e Novelas

\begin{tabular}{|c|c|c|c|}
\hline Título & $\begin{array}{c}\text { Província / } \\
\text { Estado }\end{array}$ & Periódico & Data de Publicação \\
\hline O Paraíso dos gatos & Bahia & O Monitor & $07 / 05 / 1878$ \\
\hline \multirow[t]{2}{*}{ A Morte do rico } & Ceará & Gazeta do Norte & $20 / 01 / 1882$ e $21 / 01 / 1882$ \\
\hline & Paraíba & Gazeta da Parahyba & 09/04/1889 e $10 / 04 / 1889$ \\
\hline A Morte de Olivier Bécaille & Maranhão & Pacotilha & $18 / 02 / 1884$ a $01 / 03 / 1884$ \\
\hline \multirow[t]{4}{*}{ Lili } & Maranhão & O Paiz & $10 / 09 / 1884$ \\
\hline & \multirow[t]{2}{*}{ Pará } & Diário de Belém & $18 / 09 / 1884$ \\
\hline & & Monte-Alegrense & 19/12/1886 a $02 / 01 / 1887$ \\
\hline & Ceará & Libertador & $25 / 11 / 1886$ \\
\hline \multirow[t]{2}{*}{ O Assalto ao moinho } & Pará & Diário de Belém & $11 / 01 / 1885$ a $20 / 01 / 1885$ \\
\hline & Ceará & O Cearense & $21 / 11 / 1886$ a $12 / 12 / 1886$ \\
\hline A Fada amorosa & Ceará & Libertador & $17 / 04 / 1886$ \\
\hline Simplício & Ceará & Gazeta do Norte & $30 / 11 / 1886$ a $15 / 12 / 1886$ \\
\hline \multirow[t]{2}{*}{ Os Morangos } & Maranhão & Pacotilha & $11 / 10 / 1886$ \\
\hline & Pará & Monte-Alegrense & $21 / 11 / 1886$ e $28 / 11 / 1886$ \\
\hline \multirow{2}{*}{$\begin{array}{c}\text { A Vilazinha } \\
\text { A Pequena aldeia }\end{array}$} & \multirow[t]{2}{*}{ Maranhão } & Pacotilha & $13 / 11 / 1886$ \\
\hline & & Pacotilha & $26 / 05 / 1894$ \\
\hline \multirow[t]{4}{*}{ A Mantilha Azul do Amor } & \multirow[t]{2}{*}{ Ceará } & Libertador & $17 / 12 / 1886$ \\
\hline & & A Constituição & $03 / 07 / 1888$ \\
\hline & Maranhão & Pacotilha & $31 / 12 / 1886$ \\
\hline & Paraíba & Gazeta da Parahyba & $22 / 12 / 1888$ \\
\hline Nantas & Bahia & A Locomotiva & $11 / 11 / 1888$ a $15 / 04 / 1889$ \\
\hline Os Ombros da marquesa & Pará & Diário de Belém & $31 / 03 / 1889$ \\
\hline \multirow[t]{2}{*}{ A Inundação } & Pernambuco & Jornal do Recife & $25 / 04 / 1889$ a $22 / 05 / 1889$ \\
\hline & Paraíba & Estado da Parahyba & 06/05/1891 a 04/06/1891 \\
\hline O Jejum & Pará & A República & $12 / 06 / 1892$ \\
\hline O Ferreiro & Maranhão & Pacotilha & $29 / 03 / 1894$ \\
\hline $\begin{array}{c}\text { As Aventuras do grande } \\
\text { Sidoine e do pequeno } \\
\text { Mederic }\end{array}$ & Pará & O Pará & 21/09/1899 \\
\hline História de um cão vadio & Amazonas & Jornal do Commercio & $04 / 07 / 1909$ \\
\hline
\end{tabular}

Pelo exame dos periódicos, percebemos o número elevado de narrativas curtas que apareceram nas regiões Norte e Nordeste do país em proporção aos romances aí publicados (Tabela 1), ainda mais se levarmos em conta o descrédito com que esses contos e novelas são vistos pela fortuna crítica da obra de Zola. A maioria dos contos e novelas se concentra nas 
décadas de 1880 e 1890, coincidindo com o momento em que Zola se dedica à escrita das séries Os Rougon-Macquart e As Três Cidades, já como um escritor de grande projeção internacional. A década de 1860, na qual parte dos contos havia sido publicada na França, assim como os romances iniciais, não apresenta ocorrência alguma. Na década de 1870, quando Zola publica 8 volumes dos Rougon-Macquart - sendo o sétimo o de maior relevância: A Taberna (L'Assommoir, 1877), romance considerado imoral pela crítica (MARTINS, 2019, Anexos) -, só encontramos um conto. O mesmo ocorre na década final de nosso período de estudo. Além disso, observamos o modo de funcionamento da imprensa daquele momento, que se serve do artifício de republicação de textos já traduzidos e publicados em outros jornais e estados, indicando que a prática da imprensa oitocentista de reaproveitar notícias de outros periódicos se estende igualmente aos textos literários.

\section{Contos e novelas recorrentes}

Pelas fontes consultadas, foi possível determinar que "A Morte do rico", "Os Morangos", “O Assalto ao moinho", “A Vilazinha", “A Inundação”, "Lili” e “A Mantilha Azul do Amor" apareceram mais de uma vez na imprensa - os dois últimos com quatro publicações e os demais com duas cada (Tabela 2).

"A Morte do rico" saiu no Ceará na seção "Varia" do periódico liberal Gazeta do Norte em 20-21/01/1882, portanto, aparece aqui no mesmo ano em que sai em volume na França. ${ }^{18}$ Isso demonstra, mais uma vez, que os editores dos jornais estavam atentos às novidades literárias lançadas na França para agradar a seus leitores. Desde seu surgimento, em 1880, o jornal cearense publicou em seu folhetim apenas obras de escritores franceses como Octave Feuillet, Albert Delpit, Fortuné du Boisgobey, Pierre Delcourt, Constant Guéroult e do próprio Zola, pois, Thereza Raquin aí havia sido traduzido em 1880 (Tabela 1). A constância desses autores franceses e a tradução e/ou publicação de suas obras levam-nos a crer que os leitores

\footnotetext{
${ }^{18}$ A edição Charpentier traz como data de publicação 1883, conforme o site da Biblioteca Nacional da França (https://gallica.bnf.fr/ark:/12148/bpt6k1030301/f3.image.texteImage). No entanto, tanto os Cahiers naturalistes (http://www.cahiers-naturalistes.com/catalogue oeuvre.html) quanto o Dictionnaire d'Émile Zola (BECKER et al., 1993, p. 63) afirmam que o ano de lançamento é 1882. É mais provável que a recolha de novelas tenha sido lançada em 1882. Isso explicaria seu aparecimento no Brasil nesse mesmo ano.
} 


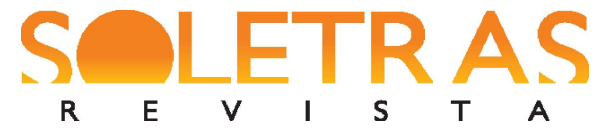

R E V I S
A

N. 40 - 2020.2 - EDUARDA ARAÚJO DA SILVA MARTINS PEDRO PAULO GARCIA FERREIRA CATHARINA

desse jornal estavam habituados à leitura de romances populares e que apreciavam especialmente a literatura francesa. Em 09-10/04/1889, a mesma tradução do conto foi publicada no corpo do jornal Gazeta da Parahyba, periódico de pequena circulação, com tiragem diária de 800 exemplares, que também, até então, só havia publicado folhetins de escritores franceses populares, hoje esquecidos, como Fortuné du Boisgobey, Jules Mary e Achille-J. Dalsème.

"A Morte do rico", de O Capitão Burle, é uma novela de cunho sociológico que descreve o final da vida de um aristocrata francês. Proprietário de uma grande fortuna, o Conde de Verteuil é acometido por uma doença que o leva rapidamente à morte. $\mathrm{O}$ conto, carregado de refinada ironia naturalista, revela a vida de casado do conde, seu breve processo de adoecimento, sua morte e seu funeral. O narrador extradiegético percorre a vida do casal, revelando um casamento de fachada sem amor e fundamentado nas aparências: "Há certo tempo que romperam toda a casta de relações; não obstante, são bons amigos e egoístas. Consultamse, apresentam-se como namorados perante a sociedade, mas depois retira-se cada qual para os seus aposentos, onde recebem os amigos íntimos" (Gazeta do Norte, 20/01/1882, p. 3). ${ }^{19}$

O narrador revela ainda o descaso da esposa do moribundo que, sem demonstrar grande afeto pelo marido, mantém sua rotina apesar da morte iminente do conde. Após a morte do aristocrata, o narrador descreve com precisão o cortejo fúnebre com o carro de "primeira classe" e os cavalos ostentando "ricos penachos". Muitas personalidades da sociedade compareceram ao funeral; todo o clero estava na igreja, onde o célebre cantor de ópera Jean-Baptiste Faure realizou uma apresentação. Comenta ironicamente o narrador: "Nunca ele cantou melhor. Faz pena que o pobre Verteuil não possa ouvi-lo”. O conto termina com a descrição do estado inerte e pouco afetado da condessa diante da perda do marido: "E a condessa não se moveu da embaladeira. Continua entretida com o cordão do cinto, de olhos fitos no chão, entregue a pensamentos, que por fim devolvem a perdida cor às faces da encantadora loira". "A Morte do rico" é, portanto, uma novela de estética naturalista que revela as futilidades e o egoísmo da aristocracia francesa.

\footnotetext{
${ }^{19}$ As demais citações deste conto e dos seguintes, quando não referidas, encontram-se na mesma página da primeira referência.
} 
O conto "Os Morangos", de Novos Contos a Ninon, publicado em outubro de 1886 na seção "Variedade" do Pacotilha do Maranhão, foi republicado no mês seguinte no folhetim do Monte-Alegrense do Pará, com a mesma tradução. O texto relata um passeio do narrador em um bosque com Ninon. Caminhando entre as plantas, Ninon vê morangueiros e passa a buscar pela fruta. Após uma hora, ela encontra apenas um morango, que divide com o narrador:

Tivemos, porém, outra história para saber qual de nós comeria essa frutinha que nos havia custado boa hora de trabalho. Ninon queria por força que eu comesse. Eu resistia; mas depois acabei por consentir e resolveu-se que o morango seria partido ao meio. Ela então levou a fruta à boca dizendo-me com um sorriso:

- Vamos toma o teu.

Tomei o que me cabia. Não sei se a fruta foi partida irmãmente. Não sei mesmo se senti o gosto do morango, tão doce me pareceu o mel do beijo de Ninon. (Pacotilha, 11/10/1886, p. 2)

Trata-se da representação de um amor juvenil, idealizado pela atmosfera campestre, revelando-se naturalmente sensual. Os amantes acabam por encontrar morangueiros fartos em uma colina e iniciam a colheita da fruta que lhes servirá de almoço. Com os morangos em mãos, buscam o lugar ideal para um piquenique improvisado. Zola trabalha com um jogo de imagens naturais e pastoris, descrevendo a simplicidade da vida no campo, que se traduz em uma visão erótica da relação dos jovens que passeiam sem se preocupar com as normas da sociedade:

A alguns passos dali deparou-se-me um retiro encantador, um verdadeiro ninho de folhedo. O lenço foi religiosamente colocado ao nosso lado.

Oh! Como estava-se bem ali, sobre o musgo, na volúpia dessa frescura verde! Ninon olhava-me com os olhos úmidos. O sol havia roseado-lhe suavemente o colo. Vendo o meu olhar todo ternura, ela inclinou-se para mim estendendome as mãos com um gesto de adorável abandono. [...]

Quando procuramos os morangos para comê-los, qual não foi o nosso espanto vendo que tínhamo-nos deitado bem em cima do lenço! 


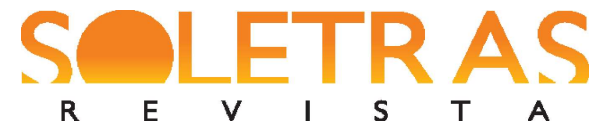

A N. 40 - 2020.2-EDUARDA ARAÚJO DA SILVA MARTINS PEDRO PAULO GARCIA FERREIRA CATHARINA

A novela naturalista "O Assalto ao moinho", de Os Saraus de Médan, é outra narrativa curta que aparece ao menos duas vezes nas regiões Norte e Nordeste. Sua primeira publicação se deu entre os dias 11 e 20 de janeiro de 1885 pelo periódico Diário de Belém. No dia do primeiro folhetim, uma nota é inserida no corpo do jornal:

O conto de Emilio Zola, cuja tradução encetamos hoje, é um episódio pungente e comovedor da guerra franco-prussiana, pintado com a intensidade de cores, a vida e a fidelidade, que são principais características do elevado talento do célebre romancista francês; averiguando-se ainda, da leitura do mesmo conto, que o seu autor não é tal um indecente pornográfico, como os críticos seus adversários pretendem a viva força fazer acreditar.

Aos nossos dignos leitores e amáveis leitoras, recomendamos este interessante trabalho, cuja tradução devemos a obsequiosidade de um amigo que tem tanto de inteligente e ilustrado, quanto de modesto. (Diário de Belém, 11/01/1885, p. 2)

Nessa nota, além de indicar o contexto histórico da novela, o jornalista destaca a qualidade literária do texto a partir das características da literatura naturalista de Zola: o escritor cria "com a intensidade de cores, a vida e a fidelidade". A análise positiva da novela, que ele chama de conto, se contrapõe à imagem de escritor pornográfico, frequentemente veiculada por parte da crítica e da imprensa. O jornalista tenta convencer os "dignos leitores e amáveis leitoras" de que a obra que publica é séria e não imoral, protegendo-se, desse modo, dos efeitos da má reputação de escritor pornográfico, criada sobretudo na década anterior, quando Zola lançou A Taberna. Outro ponto interessante a observar é o fato de a tradução ter sido realizada especificamente para este jornal, como reitera o subtítulo do primeiro folhetim: "O Assalto ao Moinho por Émile Zola; traduzido para o Diário de Belém". Infelizmente, o periódico não nomeia o tradutor, que pode ter sido o próprio editor do jornal. O leitor do Diário de Belém parece apreciar a estética naturalista, pois o folhetim que segue "O Assalto ao moinho" é a novela "Em família" ("En famille”), do escritor naturalista Guy de Maupassant.

A segunda ocorrência de "O Assalto ao moinho" surge no ano seguinte, entre novembro e dezembro de 1886 em $O$ Cearense, periódico de tendência liberal que publica a mesma tradução da novela, sem dar os devidos créditos ao periódico paraense. O Cearense não havia lançado muitos folhetins no ano de 1886. Antes de "O Assalto ao moinho", veicula apenas um 


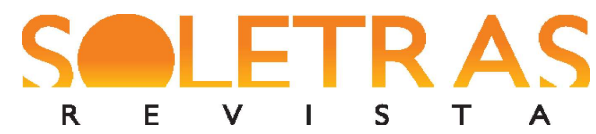

N. 40 - 2020.2 - EDUARDA ARAÚJO DA SILVA MARTINS

PEDRO PAULO GARCIA FERREIRA CATHARINA

texto longo seriado, o romance de aventuras Mathias Sandorf, de Jules Verne, o conto A coroa murcha, de Catulle Mendès, ambos escritores franceses, e uma narrativa curta sem indicação de autor intitulada $O$ médico indigente - romance irlandês.

A novela se inicia revelando a habilidade descritiva de Zola que "pinta" a propriedade do senhor Merlier, prefeito da cidadezinha de Rocreuse, onde possui um moinho:

\begin{abstract}
E era aí que o moinho do pai Merlier alegrava com seu tic-tac um canto de verdura exuberante. $\mathrm{O}$ edifício, de barro e tábuas, parecia velho como o mundo, e mergulhava até ao meio no Mosella [sic], que arredonda nesse lugar uma bacia transparente. Levantava-se uma represa e a água caía da altura de alguns metros na roda do moinho, que estalava ao girar, como a tosse asmática de uma criada fiel envelhecida ao serviço da casa. [...] Quando a água batia-a com a sua onda de prata, ela cobria-se de pérolas e via-se passar a informe carcaça paramentada de brilhantes colares nacarados. ( $O$ Cearense, 21/11/1886, p. 2.)
\end{abstract}

A filha de Merlier, Françoise, é noiva de seu vizinho, um rapaz belga chamado Dominique. Pouco antes do casamento, soldados franceses ocupam a propriedade. O moinho passa a funcionar como um forte contra o ataque do inimigo. Dominique defende a noiva, juntando-se ao exército francês na luta contra os prussianos. Estes conseguem invadir a propriedade após a retirada do exército francês. Dominique é condenado pelos alemães ao fuzilamento e Françoise o convence a fugir. Ao descobrirem a fuga, os alemães ameaçam a vida de Merlier. A jovem encontra o noivo, porém não consegue pedir para que volte, regressando sozinha para casa. Os oficiais preparam o fuzilamento de seu pai quando Dominique aparece e toma o lugar do futuro sogro. Antes de o fuzilarem, no entanto, percebem a aproximação dos franceses. Françoise, então, se enche de esperança, mas o capitão dá ordem para que continuem o fuzilamento: “Antes de tudo, acabemos com esse negócio. E empurrando ele próprio Domingos [Dominique] de encontro à parede de um telheiro, mandou fazer fogo. Quando Francisca [Françoise] voltou-se, Domingos jazia por terra, com o peito furado por doze balas" (O Cearense, 25/12/1886, p. 2). 


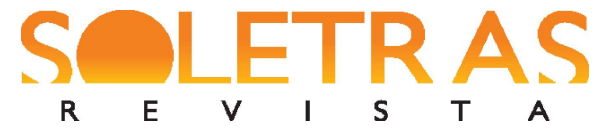

A N. 40 - 2020.2 - EDUARDA ARAÚJO DA SILVA MARTINS PEDRO PAULO GARCIA FERREIRA CATHARINA

O combate entre franceses e prussianos foi intenso e violento, causando grande destruição na propriedade. Nessa novela, Zola revela com detalhes realistas a crueldade e a destruição causada pela guerra, que pode ser vista na vida da família Merlier:

Embaixo do telheiro, Francisca não tinha se movido, agachada defronte do cadáver de Domingos. O pai Merlier tinha sido morto por uma bala perdida. Então, exterminados os prussianos, o moinho a arder, o capitão francês foi o primeiro a penetrar no pátio. Desde o começo da campanha, era o primeiro triunfo que ele alcançava. Por isso, todo inflamado, alteando o porte, ele ria, com seu ar amável de perfeito cavalheiro. E avistando Francisca, imbecil entre os cadáveres de seu noivo e de seu pai, no meio das ruínas fumegantes do moinho, cortejou-a galanteadoramente com a espada bradando:

-Vitória! Vitória!

Cheia de ação, "O Assalto ao moinho" é uma novela naturalista que apresenta uma crítica acerba contra a violência e os horrores da guerra que afetam uma cidade pacífica e seus habitantes. A ironia age no contraste entre a destruição da propriedade de Merlier e a atitude do capitão francês. O brado de vitória simboliza o chauvinismo cego do exército francês e a insensibilidade dos responsáveis pela guerra para com os cidadãos inocentes. Zola realiza, por meio do projeto dos Saraus de Médan, uma crítica à política do Imperador Napoleão III, que resultou na esmagadora derrota da França.

A mesma crítica já teria aparecido no conto "A Vilazinha", de Novos Contos a Ninon. Esse conto foi publicado em duas décadas diferentes (Tabela 2) no Pacotilha do Maranhão. A primeira vez é indicado que a tradução foi feita pelo Diário de Belém, sugerindo, portanto, que o conto saiu duas vezes nessa década, embora não tenha sido possível encontrar a edição do Diário de Belém que o publicou. A tradução leva o título de "A Vilazinha". A segunda publicação apresenta uma tradução diferente com o título "A Pequena aldeia”. Como em "O Assalto ao moinho", Zola descreve as belezas de uma cidade do interior e, em seguida, revela como a guerra a afeta negativamente. "A Pequena aldeia" parece, assim, ter servido de laboratório inicial para a escrita de "O Assalto ao moinho", cujo tema também reaparecerá na composição do décimo nono volume dos Rougon-Macquart - romance publicado no país, como visto, com o título $O$ Desmoronamento (Tabela 1). Zola trabalhou a mesma temática nas duas 


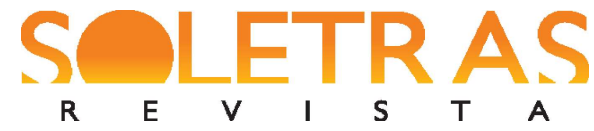

R $\quad$ E
$T$
A

narrativas curtas, embora as diferenças estéticas sejam evidentes. Em "A Pequena aldeia”, com a descrição bucólica do vilarejo, há um tratamento mais romântico do tema do que em "O Assalto ao moinho":

Suas cabanas, semelhantes a castas banhistas, desaparecem por entre os vinhedos da ribanceira. Serve-lhe de tapete um pedaço de verdejante prado; [...] Dorme silenciosa no fundo de sua alcova verde.

Nenhum de nós a conhece.

A vizinha cidade sabe apenas que ela existe, tão humilde, que geógrafo algum dela cuidou. [...] $\mathrm{Na}$ turba das cidades, entre os nomes brilhantes, é desconhecida, sem história, sem glória e sem torpezas, que modestamente se escureçam. E é por isso, talvez que ela, a pequena aldeia, sorri docemente. (Pacotilha, 16/05/1894, p. 2)

Nesse conto, no entanto, já é possível notar de forma atenuada as personificações comumente usadas por Zola em seus romances, como em "dorme silenciosa", "tão humilde", "sorri docemente". O escritor compara a aldeia a uma desconhecida que vive feliz em seu isolamento.

Outra narrativa publicada nos jornais nas décadas de 1880 e 1890 é a novela "A Inundação", tirada de $O$ Capitão Burle. Sua publicação acontece entre os dias 25 de abril e 22 de maio de 1889, no Jornal do Recife. A outra publicação sai entre 6 de maio e 4 de junho de 1891, no Estado da Parahyba. Pela primeira vez dentro deste corpus é indicado o tradutor, porém apenas por iniciais. No Jornal do Recife, lê-se: "Versão de E. C. (Para o Jornal do Recife)". No Estado da Parahyba, lê-se: "Versão de A. de S". Trata-se de traduções diferentes da mesma novela, e, portanto, não houve réplica do texto.

Em “A Inundação", há mais uma vez a pintura de uma cidade do interior da França, onde seus habitantes vivem em conjunção com uma natureza harmoniosa. Entretanto, diferentemente dos dois contos que trazem a temática da vida do interior ("O Assalto ao moinho" e "A Pequena aldeia"), o que vem perturbar o estado de equilíbrio do local e dos personagens não é a guerra, mas um fenômeno natural, o transbordamento do rio Garonne que passa próximo à propriedade de Louis Robineau, narrador da novela, homem rico que vive com sua família da fartura de sua propriedade. A inundação carrega gradativamente os animais, as 
criadas, a esperança, a casa e a família do patriarca. A novela é construída mostrando a ascensão da família até o cume da casa, em busca de abrigo. À medida que os personagens sobem do térreo para o segundo andar e do segundo andar para o telhado, percebe-se a ruína da família. ${ }^{20}$

"A Inundação" retoma em inúmeros aspectos a trama e os personagens da quarta parte da novela-romance "As quatro jornadas de Jean Gourdon" - "Inverno" -, publicada originalmente entre 1866 e 1867 e reunida em Novos Contos a Ninon. Em ambas é forte a demonstração da luta darwiniana do homem pela sobrevivência e contra as forças da natureza. As marcas da realidade e da atualidade se fazem presentes: "A Inundação" foi publicada em 1875, ano em que o rio Garonne havia transbordado e arruinado inúmeras famílias, servindo, assim, de tema para a novela.

"Lili", de Novos Contos a Ninon, publicado quatro vezes segundo nossos dados, foi subdividido por Zola em três partes. Apenas a segunda foi publicada na seção "Variedades", em 1884, no Paiz do Maranhão. O mesmo conto apareceu logo depois nas "Variedades" do Diário de Belém, no Pará. Trata-se da mesma tradução na qual faltam a primeira e a última partes. A escolha dos jornais em publicar apenas a segunda parte é particularmente interessante, já que ela se distingue fortemente da primeira e da terceira.

Como mostra a tradução completa realizada pelo Libertador do Ceará, dois anos depois, "Lili" se inicia e se conclui com um tom bucólico e romântico. A segunda parte do conto, porém, pode ser lida independentemente, pois o narrador relata uma experiência vivida em Paris, quando, em uma tarde, observa no Jardim das Tulherias o comportamento de uma menina de seis ou sete anos chamada Lili. O tom do conto muda e percebemos um narrador agindo como um observador naturalista, atento e malicioso, que descreve em primeira pessoa, com grande habilidade, a precocidade e a altivez (e talvez o ridículo) de uma menina de classe alta imitando uma mulher adulta. Pode-se dizer, então, que a segunda parte do conto se aproxima muito mais da estética naturalista do que a primeira e a terceira partes, já que o escritor descreve de maneira pouco idealizada e ironicamente o comportamento da criança:

\footnotetext{
${ }^{20}$ Um movimento similar ocorre em Le Père Goriot (1835), de Balzac. A decadência financeira, física e moral do protagonista é inversamente proporcional à sua ascensão dos andares da pensão onde habita. Porém, se em Balzac o deslocamento assume um caráter metafórico, aqui não parece haver nenhum elemento simbólico explícito.
} 
Era uma mulher pequenina. Fiquei verdadeiramente aterrado com a sua sisudez e a sua ciência. Não tinha ainda 7 anos e já sabia o seu mister de encantadora. É só em Paris que se encontram rapariguinhas tão precoces conhecendo a dança antes de conhecer as letras. Quanto me lembram as crianças da província!

São desairosas e pesadas, arrastam-se brutalmente pelo chão. Não era, decerto, Lili que ia estragar assim a sua bela toilette; preferia não brincar; conservavase muito firme dentro de suas saias engomadas, contentando-se com ser vista, com ouvir dizer de si: "Oh! criança tão galante!" [...]

[Lili] Sabia mentir como sabia ser bela. Faltava-lhe só crescer; não ignorava lá coisa alguma do que faz uma mulher bonita.

Com semelhante educação como querem que os pobres maridos durmam tranquilos? (O Paiz, 10/09/1884, p. 3)

É provável que a escolha feita pelo jornal não tenha sido fortuita. Sendo Zola, em 1884, reconhecido mundialmente por sua produção naturalista, o periódico parece não querer apresentá-lo de outra maneira. Talvez tenha sido por isso que escolheu publicar somente a segunda parte, suprimindo a primeira e a última, mais próximas da estética romântica. Em 1886, o conto voltou a aparecer nos jornais. O Libertador do Ceará publicou nova tradução completa em novembro e, nos meses seguintes, foi a vez do jornal Monte-Alegrense do Pará publicá-lo seriado em seu folhetim em dezembro de 1886 e janeiro de 1887. Nos dois casos, trata-se da mesma tradução. Encontramos, portanto, duas traduções de "Lili", uma em 1884, veiculada no Paiz e no Diário do Maranhão e outra, em 1886-1887, pelo Libertador e o Monte-Alegrense.

O método de reprodução de tradução de textos literários de um jornal para o outro ocorreu também com “A Mantilha Azul do Amor”, de Novos Contos a Ninon, que teve sua publicação completa em 17/12/1886 no Libertador do Ceará e, em menos de 15 dias, no Pacotilha do Maranhão. Dois anos mais tarde, o conto ressurge no Ceará, em A Constituição, de 03/07/1888 e, cinco meses depois, na Gazeta da Parahyba. Trata-se da mesma tradução.

“A Mantilha Azul do Amor" é um conto dividido em quatro partes que trata de uma jovem órfã apelidada de "Mantilha Azul do Amor", provavelmente em referência a uma santa. Essa jovem curava as dores dos andarilhos, distribuindo-lhes beijos e esmolas. No entanto, a linguagem ambígua apresenta não a vida de uma santa que se doa em prol dos necessitados, mas aquela de uma espécie de prostituta caridosa, que se oferece para todo tipo de homem: 
A encantadora donzela somente distinguiu-se nestas graves circunstâncias. Estabeleceu ambulâncias, tratou os enfermos noite e dia, sarando as feridas com os seus beijos e agradecendo ao céu a sina que lhe dera.

Foi uma providência para os moços; salvou muitos deles. Aqueles a quem ela não pôde curar os corações era que já não os possuíam.

Seu remédio era muito simples, dava aos doentes suas mãos compassivas, seu hálito morno. Jamais exigiu que lhe pagassem. Arruinava-se descuidosa, distribuindo esmolas às mãos largas. (Gazeta da Parahyba, 22/12/1888, p. 3)

O final do conto é carregado de ironia, traço recorrente em obras naturalistas. Tendo gastado praticamente todas as suas "moedas" (entende-se moedas por juventude ou beleza), a mulher procura um homem a quem entregue o pouco que sobrava de seus dotes e que a sustente, agora que não goza mais de sua "fortuna":

Um dia achou vazio o coração. Estremeceu horrorizada, restavam-lhe apenas algumas moedas de ternura, e a peste continuava.

[...] Por um instante pensou em guardar preciosamente algumas moedas que ainda restavam-lhe e despende-las com toda a prudência; mas sentiu-se tão fria no seu isolamento que saiu procurando os raios do sol de Maio.

$\mathrm{Na}$ estrada, chegando ao primeiro marco, encontrou um moço, cujo coração morria enfraquecido. Vendo isto, despertou ardentemente a caridade da donzela; não podia trair a sua missão. E cintilante de bondade, grande de abnegação, pôs sobre os lábios tudo o que havia em seu coração, inclinou-se docemente, beijou o moço e disse-lhe;

- Toma, é a minha derradeira esmola. Paga-me agora.

Ao final, a generosidade da mulher adquire uma nota amarga de realismo, pois a Mantilha Azul do Amor acaba por exigir um pagamento, revelando não apenas o lado sexual dadivoso da vida da personagem, subentendido ao longo da história, mas também suas necessidades financeiras. O texto termina com a seguinte frase: "Não tem moralidade a legenda da Mantilha Azul do Amor", revelando que o narrador, à maneira naturalista, não julga o comportamento do personagem.

Uma leitura menos atenta poderia associar "A Mantilha Azul do Amor" ao conto maravilhoso e moralizante "Irmã-dos-Pobres", de Contos a Ninon, escrito originalmente para 


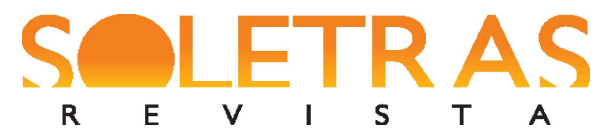

N. 40 - 2020.2 - EDUARDA ARAÚJO DA SILVA MARTINS

PEDRO PAULO GARCIA FERREIRA CATHARINA

crianças e não veiculado pelos jornais analisados. Esse conto narra a história de uma jovem generosa que recebe da Virgem Maria uma moeda mágica que se multiplica infinitamente. Ela pode, assim, ajudar os necessitados, mas, ao final, devolve o pernicioso presente à Virgem, preferindo ganhar a vida pelo trabalho (BECKER et al., 1993, p. 88). Esse desenlace já traz a nota materialista sobre a qual se constrói a obra de Zola. Deste conto para "A Mantilha Azul do Amor" a narrativa, altamente antirreligiosa, ganha em ironia naturalista. Isso marca um maior distanciamento para com a temática religiosa e moralizante, pela ironia presente desde o título original - "La légende du Petit-Manteau bleu de l'amour" - que remete às antigas hagiografias e a textos modernos como os que Gustave Flaubert criará em Três Contos (Trois Contes, 1877). Pela releitura do gênero, Flaubert narra o percurso de "existências exemplares", sendo que aquela de Félicité, em "Um coração simples" ("Un Cœur simple”), se elabora dentro da estética naturalista ao propor uma mártir moderna da vida banal da província. A temática reaparecerá em 1888 no romance-conto de fadas de Zola - O Sonho (BECKER et al., 1993, p. 359-360) (Tabela 1). Este romance encerra em um ambiente religioso Angélique, órfã adotada por um casal de bordadores de paramentos religiosos, que lê avidamente a Légende dorée de Voragine (1261-1266), recolha de vidas de santos e mártires que serve ao autor como "estrutura da intriga e o modelo estilístico de sua narração" (GEFEN, 2009, p. 60).

\section{Considerações finais}

Como demonstra Hemmings no artigo "Les sources d'inspiration de Zola conteur" (1968), a imaginação criativa do Zola contista o aproxima dos poetas românticos Victor Hugo e Alfred de Musset. Hemmings analisa brevemente Contos a Ninon, buscando revelar algumas referências literárias do escritor: as descrições de florestas teriam sido "inspiradas" em Contemplações (Contemplations, 1856), de Hugo; Cenas da vida boêmia (Scènes de la vie bohème, 1851), de Henri Murger, teria servido de tema para a pintura dos costumes de estudantes; viagens imaginárias teriam sido "inspiradas" em Voltaire; e, também, as Fábulas (1668-1694) de La Fontaine teriam fornecido a Zola elementos para criar suas narrativas.

Segundo van Tooren, alguns especialistas costumam distinguir duas fases da trajetória literária de Zola: uma romântica, associada às narrativas curtas, e outra naturalista, associada à 


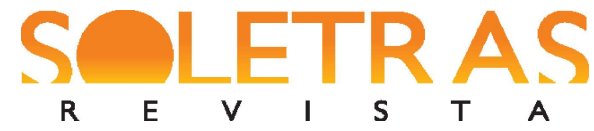

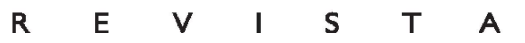

N. 40 - 2020.2 - EDUARDA ARAÚJO DA SILVA MARTINS PEDRO PAULO GARCIA FERREIRA CATHARINA

sua produção romanesca. Eles acreditam que "o ciclo dos Rougon-Macquart representaria a parte realista/naturalista, os Contos e novelas - e em especial os primeiros textos - constituiriam a parte romântica, feérica, mística" (VAN TOOREN, 1998, p. 38). Essa divisão é redutora e simplista. Evidentemente, Zola foi leitor dos grandes românticos em sua juventude, e essas leituras constituem referências para sua obra. Some-se a isso o fato de o escritor ter crescido no Sul da França, na região de Aix-en-Provence, local que proporcionou o cenário bucólico de parte de seus contos. Suas primeiras narrativas curtas surgem, provavelmente, de experiências pessoais, tornando-se em parte uma escrita íntima na qual são incutidas experiências vividas na adolescência do escritor. Devemos, contudo, analisar mais de perto as narrativas breves de Zola, antes de reduzi-las a uma fase puramente romântica. Se Contos a Ninon apresenta marcas românticas, eles trazem igualmente a questão da representação do real que se desenvolverá nos anos seguintes. Como visto nas análises propostas neste artigo, os contos oriundos de Novos Contos a Ninon ("Lili", "A Mantilha Azul do Amor”, "Os Morangos” e "A Vilazinha”/“A Pequena aldeia”) ou de O Capitão Burle (“A Morte do rico" e “A Inundação"), embora possam apresentar certo subjetivismo do narrador, insistindo em descrições bucólicas e na nostalgia de uma vida simples, tendem a conter elementos característicos do naturalismo.

Os contos e novelas de Émile Zola serviram, como tentamos demostrar, como um laboratório para sua escrita romanesca. Pelo corpus examinado, percebemos marcas de seu temperamento naturalista já patentes nas habilidosas descrições, no uso corrente da personificação, no materialismo e no tratamento irônico dado às suas narrativas curtas que, muitas vezes, se reelaboram em temas recorrentes e chegam até a obra romanesca. Na direção inversa, assinalamos en passant a existência de estudos que demonstram que a obra naturalista madura do autor possui elementos próximos do romantismo (NOIRAY, 2016). Diante disso, conclui-se que não se pode separar o Zola das narrativas curtas do Zola romancista: "não houve dois Zola, um jovem poeta idealista, ao qual teria sucedido o romancista do real" (BECKER, 1993, p. 90 in VAN TOOREN, 1998, p. 39). O célebre escritor naturalista pode ter tido suas raízes fundadas no romantismo, mas sua produção literária revela, desde cedo, uma autenticidade enquanto contista e, mais tarde, enquanto romancista. O temperamento sobre o qual discorre no Romance Experimental se revela em toda a sua produção literária, de modo 
que devemos entender a obra do escritor mais dentro de uma continuidade do que marcada por rupturas.

A presença dos contos de Zola em periódicos do Norte e do Nordeste do Brasil entre 1878 e 1909 se torna mais constante a partir da década de 1880, estendendo-se em menor quantidade até a década de 1900. O primeiro romance do autor só será publicado nos jornais dessas regiões em 1880 (Tabela 1), década de maior incidência de suas narrativas curtas. Esta é também a década em que se concentra a maior parte dos anúncios das obras do escritor à venda em livrarias ou ao alcance do leitor, sendo que quase não há anúncios na década de 1870 . Nesta última, apenas um conto havia sido publicado nas páginas dos periódicos dessas regiões e nenhum romance do escritor foi encontrado. No entanto, toda a obra do escritor estará disponível ao público leitor nas décadas seguintes, o que explicaria o declínio da publicação de contos e novelas nos jornais, pois eles poderiam ser encontrados em português e em francês em livrarias locais, grêmios, gabinetes de leitura e bibliotecas. ${ }^{21}$

Tendo em vista que a legitimação de um escritor no espaço literário nacional faculta sua entrada em espaços internacionais (CASANOVA, 2002, p. 32), acreditamos que as obras de Zola circularam no Brasil sobretudo após seu reconhecimento na França. Isso pode ser explicado pelo desenvolvimento da sua carreira ao longo da década de 1880. Ao analisarmos sua trajetória, notamos que ele foi reconhecido, sobretudo, na década de 1880, após o sucesso de vendas dos romances A Taberna, Naná e a aclamação da crítica com Germinal (1885) (PAGÈS, 1989). Essa hipótese se coaduna com a pesquisa efetuada anteriormente sobre a recepção de $A$ Taberna no Brasil (MARTINS, 2019). Embora esse romance tenha sido um dos maiores sucessos de escândalo ao ser lançado em 1876-1877 e tenha alçado seu autor a uma nova posição no campo literário francês, $A$ Taberna não foi traduzido e publicado imediatamente no Brasil, ainda que a imprensa tenha produzido algumas críticas sobre ele.

Entendendo então que o reconhecimento de Zola na França se deu por meio de sua obra romanesca, por qual razão suas narrativas curtas tiveram maior acolhida em regiões do Brasil? Uma primeira hipótese, mais evidente, seria a de que a imprensa teria privilegiado a publicação de contos e novelas por serem textos fáceis de ler, mais curtos e de mais rápida tradução

\footnotetext{
21 A pesquisa sobre os anúncios dos livros de Zola e seus locais de venda ou de consulta foi efetuada para elaboração de um artigo publicado nos Cahiers naturalistes (CATHARINA; MARTINS, 2019)
} 
(BECKER et al., 1993, p. 87), podendo ser publicados em poucas ou em uma única edição do periódico. No entanto, como foi apontado, vários jornais nos quais saíam os textos de Zola publicavam romances franceses em folhetim - mas não aqueles do escritor. Logo, a extensão não explicaria a preferência pela publicação de narrativas curtas.

Certamente seria preciso reconstituir o contexto cultural e histórico daquelas regiões do Brasil naqueles momentos precisos para entendermos melhor como essas narrativas foram apropriadas e significadas pelo leitor, já que esses fatores determinam a recepção da obra nas transferências culturais (ESPAGNE, 2012; JURT, 2007). No âmbito deste artigo, levantamos a hipótese de que o público rejeitava as obras romanescas etiquetadas como imorais ou pornográficas por parte da crítica e dos jornais, como prova a nota do Diário de Belém que anuncia a publicação de o "O Assalto ao moinho" e que poderia servir de parâmetro para medir a reputação do escritor junto aos leitores brasileiros. Este dado explicaria a preferência pelas narrativas curtas de Zola, associadas a um texto mais leve em sua apresentação, com personagens menos radicais em seus comportamentos e menos desenvolvidos psicológica e socialmente. Isso não invalida o fato de que os contos e as novelas publicados já tratassem de questões sociais ou políticas, alguns imprimindo certo erotismo à trama.

Vale relembrar os temas dos contos recorrentes aqui analisados, que são comuns às obras naturalistas: a crítica à hipocrisia da burguesia e da aristocracia, presentes em "Lili" e na "A Morte do rico"; a condenação da ganância e da guerra, apontados em "O Assalto ao moinho" e "A Pequena aldeia"; o amor e a liberdade sexual, apresentados em "Os Morangos" e em "A Mantilha Azul do Amor". Os leitores dos jornais analisados pareciam, assim, não se intimidar com os temas que já indicavam a veia naturalista de Zola, desde que os contos e as novelas, no quesito estético, não chegassem às ousadias e cruezas que marcaram seus romances mais escandalosos e que causaram inicialmente forte reação da crítica e de parte dos leitores. Se esses temas são retrabalhados nos romances ao modo naturalista, seus contos e novelas parecem transitar em uma zona intermediária, entre um certo romantismo e o naturalismo que se elabora, e seriam capazes de atrair um público mais amplo e menos propenso a se arriscar em uma literatura tão arrojada, o que provavelmente determinava as escolhas dos editores de jornais. 


\section{Referências}

ABREU, Márcia. A circulação transatlântica dos impressos: a globalização da cultura no século XIX. Livro, São Paulo, n. 1, p. 115-127, maio 2011.

ABREU, Márcia (org.). Romances em movimento: a circulação transatlântica dos impressos (1879-1914). Campinas: Editora da Unicamp, 2016.

ABREU, Márcia. Uma questão de escala, não de natureza: a circulação da cultura no século XIX. Revue Étudiante des Expressions Lusophones. CREPAL, n.3, p. 265-281, dez. 2019.

BAGULEY, David. Le naturalisme et ses genres. Paris: Nathan, 1995.

BARBOSA, Marialva. Reflexões sobre a imprensa no Brasil de 1808. Estudos em Jornalismo e Mídia. Florianópolis, ano V, n. 2, p. 91-109, jul./dez. 2008.

BECKER, Colette. Féerie et fantaisie dans les Contes à Ninon. In: CABANÈS, J.-L.; SAÏDAH, J.-P. La Fantaisie post-romantique. Toulouse: P.U. du Mirail, 2003, p. 329-341.

BECKER, Colette et al. Dictionnaire d'Émile Zola; sa vie, son œuvre, son époque; suivi du Dictionnaire des "Rougon-Macquart". Paris: Robert Laffont, 1993.

BEZERRA, Valéria; GIMENEZ, Priscila. Aspectos da repercussão de Alexandre Dumas no Brasil: o romance-folhetim e a ficção nacional. Revell, UEMS, v. 1, n. 21, p. 231-255, jan/abr, 2019.

BOURDIEU, Pierre. As regras da arte. Tradução: Maria Lucia Machado. São Paulo: $C^{\text {ia }}$ das Letras, 1996.

CASANOVA, Pascale. A República Mundial das Letras. Tradução: Marina Apponzeller. São Paulo: Estação Liberdade, 2002.

CATHARINA, Pedro Paulo; MARTINS, Eduarda. Émile Zola et l'affaire Dreyfus dans la presse au Nord du Brésil. Cahiers naturalistes. Société des Amis d'Émile Zola, $65^{\mathrm{e}}$ année, n. 93, p. 123-134, 2019.

CHARLE, Christophe. Les Intellectuels en Europe au XIX siècle. Paris: Seuil, 2001 [1996].

ESPAGNE, Michel. Transferências culturais e história do livro. Tradução: Valéria Guimarães. Livro. São Paulo, n. 2, p. 21-34, ago 2012.

ESPAGNE, Michel; WERNER, Michael. La construction d'une référence culturelle allemande en France: genèse et histoire (1750-1914). Annales, Économies, Sociétés, Civilisation. $42^{\mathrm{e}}$ année, n. 4, p. 969-992, 1987. 
FERNADES, Renata Silva. O governo das províncias do Império do Brasil: os Conselhos de Governo e os Conselhos Gerais de Província nos debates parlamentares (1823-1834). 2014. 272 p. Dissertação (Metrado em História) - Universidade Federal de Juiz de Fora, Juiz de Fora (MG), 2014.

GEFEN, Alexandre. L'hagiographie, un genre contemporain. In: SÉGUY, Mireille; KOBLE, Nathalie. Passé présent. Le Moyen Âge. Paris: Editions Rue d’Ulm, 2009, p. 55-66.

GRANJA, Lucia; LUCA, Tânia Regina de (org.). Suportes e mediadores: a circulação transatlântica dos impressos (1789-1914). Campinas: Editora da Unicamp, 2018.

HALLEWELL, Laurence. O livro no Brasil. 3. ed. São Paulo: EdUSP, 2012 [1985].

HEMMINGS, F. W. J. Les sources d'inspiration de Zola conteur. Les Cahiers naturalistes. Paris: Fasquelle, n. 24-25, p. 29-45, 1963.

HOBSBAWN, Eric. A era das revoluções: 1789-1848. Tradução: Maria Tereza Lopes Teixeira e Marcos Penchel. Rio de Janeiro: Editora Paz e Terra, 1977.

HOBSBAWN, Eric. A era do capital: 1848-1875. Tradução: Luciano Costa Neto. Rio de Janeiro: Editora Paz e Terra, 1979.

HOBSBAWN, Eric. A era dos impérios: 1875-1914. Tradução: Sieni Maria Campos e Yolanda Steidel de Toledo. Rio de Janeiro: Editora Paz e Terra, 1988.

JURT, Joseph. Traduction et transferts culturels. In: LOMBEZ, C.; VON KULESSA, R. (dir.). De la traduction et des transferts culturels. Paris: L'Harmattan, 2007.

MARTINS, Ana Luiza. Imprensa, história e literatura: conjugando discursos. In: SIMÕES JR., Álvaro Santos; CAIRO, Luiz Roberto; RAPUCCI, Cleide Antonia (org.). Intelectuais e Imprensa; aspectos de uma complexa relação. São Paulo: Nankin, 2009, p. 27-44.

MARTINS, Eduarda Araújo da Silva. L’Assommoir, de Émile Zola, na França e no Brasil: de romance da classe operária a obra moral. 2019. 258 p. Dissertação (Mestrado em Letras Neolatinas) - Faculdade de Letras, Universidade Federal do Rio de Janeiro, Rio de Janeiro, 2019.

MAUPASSANT, Guy de. [correspondência]. Destinatário: A un directeur de revue (?). Paris, 24 ago. 1891.21 carta. Disponível em: http://maupassant.free.fr/corresp/cadre.php?ord=c\&num=728. Acesso em: 13 maio 2020.

MEYER, Marlyse. Folhetim: uma história. São Paulo: Companhia das Letras, 1996.

MITTERAND, Henri. Zola; Sous le regard d'Olympia 1840-1871. T.1. Paris: Fayard, 1999. 
NOIRAY, Jacques. "J'en suis et j'en enrage": Zola romantique? Revue d'histoire littéraire de la France, v. 116, n. 1, p. 137-150, 2016. DOI: 10.3917/rhlf.161.0137

OLIVERO, Isabelle. L'invention de la collection; de la diffusion de la littérature et des savoirs à la formation du citoyen au XIX ${ }^{\mathrm{e}}$ siècle. Paris: Éditions de l’IMEC, 1999.

PAGÈS, Alain. La Bataille littéraire. Essai sur la réception du naturalisme à l'époque de Germinal. Paris: Librairie Séguier, 1989.

PONCIONI, Claudia; LEVIN, Orna (org.). Deslocamentos e mediações: a circulação transatlântica dos impressos (1879-1914). Campinas: Editora da Unicamp, 2018.

THÉRENTY, Marie-Ève. La Littérature au quotidien; poétiques journalistiques au XIXe siècle. Paris: Seuil, 2007.

THÉRENTY, Marie-Ève. Mysterymania. Essor et limites de la globalisation culturelle au XIX ${ }^{\mathrm{e}}$ siècle. Romantisme, n. 160, p. 53-64, 2013/2. DOI: 10.3917/rom.160.0053

VAN TOOREN, Marjolein. Le Premier Zola; naturalisme et manipulation dans les positions stratégiques des récits brefs d'Émile Zola. Amsterdam; Atlanta: GA, 1998.

ZOLA, Émile. Le Vœu d'une morte. Paris: Achille Faure, 1866.

ZOLA, Émile. Le Roman expérimental. 5. ed. Paris: Charpentier, 1881.

ZOLA, Émile. Le Capitaine Burle. Paris: Charpentier, 1883.

ZOLA, Émile. Naïs Micoulin. Paris: Charpentier, 1884.

ZOLA, Émile. Nouveaux contes à Ninon. Paris: Charpentier, 1886.

ZOLA, Émile. Euvres complètes. ed. H. Mitterand. Paris: Cercle du Livre, 1966-1970.

ZOLA, Émile. Contes à Ninon. Chronologie et préface par Colette Becker. Paris: GarnierFlammarion, 1971.

ZOLA, Émile et al. Les Soirées de Médan. Paris: Charpentier, 1880. 


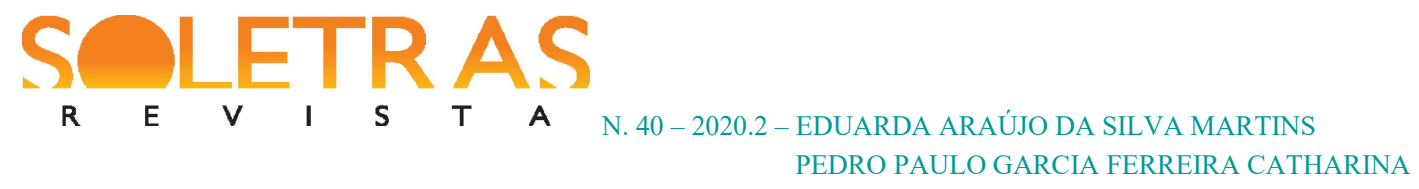

\title{
Short narratives by Émile Zola: a study on the reception of the writer's work in Brazil between 1860 and 1914
}

\begin{abstract}
In this article, by mapping short narratives written by French writer Émile Zola (1840-1902), between 1860 and 1914, published in periodicals in the North and Northeast regions of Brazil, we seek to highlight, within the scope of the writer's work, a set of texts generally placed in second place to his naturalist novelistic production, which is aesthetically and symbolically more valued by critics and academic research. This article will therefore present an analysis of the aesthetic characteristics of part of these short stories and novellas, often associated with a romantic and early phase of the writer, in order to highlight its place as a constitutive part of Zola's work. Through the research of sources, by recovering literary texts from the past inserted in the modes of operation of the 19th century Brazilian press, we add new data regarding the reception of Zola in Brazil, as well as bring to light traces of the tastes and preferences of 19th and early 20th-centuries Brazilian readers.
\end{abstract}

Keywords: Short stories and novellas. Émile Zola. Naturalism. Brazilian Press. Reception.

Recebido em: 31 de maio de 2020.

Aceito em: 18 de junho de 2020. 